\title{
Building Bridges on the Silk Road: A Strategy for Vietnam
}

\author{
A.Greiman \\ Boston University, Massachusetts
}

\begin{tabular}{|c|c|}
\hline & ABSTRACT \\
\hline $\begin{array}{l}2016 \text { Research Leap/Inovatus Services Ltd. } \\
\text { All rights reserved. } \\
\text { DOI: } 10.18775 / \text { jibrm.1849-8558.2015.55.3005 } \\
\text { URL: } \underline{\text { http://dx.doi.org/10.18775/jibrm.1849- }} \\
\underline{8558.2015 .55 .3005}\end{array}$ & $\begin{array}{l}\text { In March 2015, the Chinese government published an official document entitled "Vision and } \\
\text { Actions on Jointly Building the Silk Road Economic Belt and the } 21 \text { st-Century Maritime Silk } \\
\text { Road," commonly known by the Chinese as "One Belt, One Road" (OBOR, 2015). The } \\
\text { purpose of this massive initiative is to instill vigor and vitality into the ancient Silk Road, } \\
\text { connecting Asian, European and African countries and their adjacent seas, more closely and to } \\
\text { promote mutually beneficial cooperation to a new high and in new forms. Despite the }\end{array}$ \\
\hline $\begin{array}{l}\text { Keywords: } \\
\text { One belt, One road, Vietnam economic development, } \\
\text { Sustainability, Governance, Developing economies }\end{array}$ & $\begin{array}{l}\text { foreign direct investment in the important countries on the Silk Road and the impact of these } \\
\text { investments on the people of these less-developed regions of the world. Vietnam is a critical } \\
\text { partner in this initiative because it shares both maritime and land frontiers with China. Vietnam } \\
\text { also serves as China's largest trading partner in the Association of Southeast Asian Nations } \\
\text { (ASEAN), with two-way trade approaching } \$ 75 \text { billion in } 2016 \text {. China has always expressed a } \\
\text { preference for bilateral negotiations in the contested waters of the Maritime Silk Road, despite } \\
\text { efforts by ASEAN and other regional organizations to develop more multilateral approaches. } \\
\text { Through empirical research, this paper analyzes the challenges and opportunities for China in } \\
\text { advancing Silk Road initiatives bilaterally with Vietnam as one of its most important strategic } \\
\text { partners. The paper also sets forth Vietnam's strengths and challenges in integrating its own } \\
\text { Five-Year Development Plan into strategic partnerships, regional trade agreements and bilateral } \\
\text { arrangements on the Belt and Silk Road including how the country can improve its strategy for } \\
\text { foreign direct investment. Through integrating the development strategies of Vietnam, the } \\
\text { overall plans for expansion of the Belt and Maritime Silk Roads may become a reality, and } \\
\text { serve as a model to facilitate trade and investment throughout the region. }\end{array}$ \\
\hline
\end{tabular}

\section{Introduction}

Two thousand years ago, the States of Kazakhstan, Kyrgyzstan, Tajikistan, Turkmenistan, Uzbekistan and the four western Chinese provinces of Gansu, Ningxia, Shaanxi and Xinjiang were at the heart of the ancient Silk Road. Over time empires were destroyed, cities fell in ruins, and new forms of transport emerged, while the trade route of antiquity gradually fell into disuse for centuries. It was not until after the fall of the Soviet Union in the 1990's, that the Central Asian Countries began their transformation to market economies and became reintegrated into the world economy (UNCTAD, 2014). Importantly, the ancient Maritime Silk Road is becoming a renewed focus for both economic development and for interactions with China and its many neighbors. In recent years, there has been a new spirit of energy and the Silk Road region as a whole has experienced strong economic growth and is emerging as an important foreign investment destination (UNCTAD, 2014). A much discussed aspect of the Silk Road is "the opening up" of opportunity for China - through its One Belt, One Road Initiative. This initiative consists of two segments - One is centered on the Asian land mass and called the Silk Road Economic Belt; the other looks to the South China Sea, the South Pacific and Indian Ocean and is known as the 21st Century Maritime Silk Road (PRC, 2015). This initiative has many important advantages for sustainable development not least of which is the building of a cohesive policy among different nations, economies and cultures to facilitate trade and investment, increase financial cooperation, and promote economic development. The Plan aims to restore the country's old maritime and overland trade routes and lift the value of trade with more than 40 countries to $\$ 2.5$ trillion within a decade (Economist, 2015).

In April 2015, Chinese President Xi Jinping and Vietnamese Communist Party chief Nguyen Phu Trong agreed to work together on the Maritime Silk Road trade initiative and to set up expert task forces for infrastructure and financial cooperation (Abe and Tomiyama, 2015). This marked the first bilateral meeting of the two countries top officials since territorial 
tensions in the South China Sea heightened in May of 2014. Recently, they agreed to extending cooperation in various fields including maritime exploration, and expansion of military and security cooperation (Xinhua, 2017). Each country has much to benefit from a comprehensive, long-term strategic relationship. Vietnamese claims like China's also cover an extensive area of the South China Sea, based on historic rights. The Vietnamese have followed the Chinese example of using archaeological evidence to bolster sovereignty claims. By the end of 2016, the China Development Bank had provided loans of around 160 billion dollars in connection with the Belt and Road Project. Further contracts worth around 350 billion dollars are currently being negotiated (Kim, 2017).

Opportunities abound for Vietnam and China to improve trade opportunities, and to focus their future relationship on opportunities along the Silk Road. China has been Vietnam's largest trade partner for the last 14 years; however, Vietnam counts as one of China's most important rice suppliers. There are also shared interests as well as conflicts in the development of the Mekong River, which runs through Vietnam. Last year, the Mekong Delta attracted 1.36 billion USD worth of FDI, raising the number of foreign-invested projects to 1,324 with total registered capital of over 18.9 billion USD, accounting for 5.8 percent of the country's total project number and 6 percent in value (Vietnamnet, 2017).

The Mekong River is one of the world's largest river systems, flowing 4,909 km through six countries: China, Myanmar, Thailand, Lao PDR, Cambodia, and Vietnam. The source of the river's great productivity is its seasonal variation in water level and the range of wetland habitats inundated. The Mekong River Basin's biodiversity is immense, even in comparison with other parts of tropical Asia. Its biodiversity is fundamental to the viability of natural resource-based rural livelihoods of a population of 60 million people living in the Lower Mekong Basin (Renaud and Kuenzer, 2012). However, there are also numerous conflicts in the Mekong Delta. Vietnam's reliance on the Mekong River for its water supply is contrary to China's need for the river to provide water and electricity. To serve this need, China is currently building hydroelectric dams. In addition, complaints have come from Laos, Vietnam, and Cambodia regarding environmental damage and droughts from Chinese hydropower projects along the Mekong River (Eisenman and Stewart, 2017). The shared interest in the Mekong River is an important topic for cooperation in the development of the Silk Belt region.

On May 14, 2017, in his opening statement at the Belt and Road Forum, Peter Thomson, President of the UN General Assembly proclaimed, "The Belt and Road initiative will boost many of the sustainable development goals through economic growth, employment, poverty reduction, and expansion of trade and investment among the countries along the Belt and Road. And we have every hope it will create the conditions for sustaining peace and preventing violent extremism. This is vital to our shared future, for the United Nations has reached a clear conclusion that there can be no sustainable peace without sustainable development, and no sustainable development without sustainable peace" (UN, 2017). President Xi at a recent meeting with Vietnamese President Tran Dai Quang said the two countries should push forward maritime cooperation, accumulate consensus gradually and broaden their common interests (Xinhua/Ju Peng, 2017). This will require more than just a common vision; it will require developing a long-term partnership with strategic goals, formalized agreements, and mechanisms for enforcing the agreements.

\section{Initiatives in Opening up Relationships on the Silk Road}

An important initiative to enhance opportunity and provide guidance to the Silk Road countries was the establishment of the Asian Infrastructure Investment Bank (Weiss, 2017). The AIIB was developed in part to better unite the Asian Region in infrastructure development. To be successful, it requires improving the quality of life of the Silk Road countries, which is also a goal of China's 13th Five-Year Economic Plan (CPC, 2015), and of Vietnam's Five-Year Socio-Economic Plan (Vietnam, 2016). This requires a successful linkage between the communities and cities on the Silk Road region and the Silk Road investors and sponsors. The AIIB serves as an important source to both China and Vietnam in their endeavor to support and encourage the private sector to invest in infrastructure development. Prime Minister Nguyen Xuan Phuc during a meeting with the President of the Asian Infrastructure Investment Bank (AIIB) Jin Liqun in Hanoi on March 7, 2017 stressed that Vietnam attaches great importance to attracting private investment, including foreign investors (Hanoitimes, 2017). Vietnam should pursue investment with the AIIB that will advance socio-economic development in the countries poorer regions including developing models for investment similar to the World Bank's highly successful Kecamatan project, a community-based development project in the Republic of Indonesia, an important country on the Silk Road (Adler, 2009; Greiman, 2011; Guggenheim, 2006; Guggenheim, et al. 2004). Vietnam must also review its laws and regulations impacting foreign investors to ensure that the AIIB loans are bankable. AIIB will leverage and mobilize public and private financing, including from institutional investors, and help assist clients to enhance project "bankability" by promoting transparency, efficiency, and adherence to accepted standards including environmental and social standards - thereby reducing risk (Liqun, 2016). Obtaining AIIB loans will be a great opportunity for Vietnam to forge partnerships with other Belt and Road nations as well as obtain credibility in the international markets for project finance.

Another initiative in opening up relationships on the Silk Road is the development of bilateral relations with China to advance Vietnam's Five-Year Economic Plan officially approved at the VIIIth National Assembly's Inaugural Session, 20-23 April 
2016 (Vietnam, 2016). Vietnam's Five-Year Plan sets a framework for continued sustainable economic growth and poverty reduction in alignment with the goals of the Silk Road (p. 74). Among the outstanding issues that the Plan addresses are: (1) The wide gap between urban and rural development; (2) the reliance for economic growth mainly on natural resources; (3) lack of the monitoring and evaluation of private investment projects; (4) weak state-owned enterprise development; (5) the enforcement of the rule of law; (6) lack of coordination between central and local government agencies; and (7) limited understanding by entrepreneurs on integration and suitable response mechanisms. Importantly, as noted in the Plan, Vietnam must look to regional and transnational cooperation along with support of the private sector especially through the attraction of domestic and foreign investment. These goals should be integrated with the goals of the wider region through strategic partnerships with the Belt and Road countries as well as the investment resources dedicated to the development of integration among the various nations and cities along the Silk Road.

The financing of the Belt and Road has created significant concern, not only among the ASEAN nations, but also for investors around the world who have bet on China's success in the Belt and Road initiatives. An enormous financing commitment and platform is supporting the Belt and Road initiative. Based on analyses, Price Waterhouse Cooper (PwC) predicts that the Belt and Road will mobilize up to US \$1 trillion of outbound state financing from the Chinese government in the next 10 years. Most of this funding will come in the form of preferential debt funding, but some will be in equity. The government has created specific vehicles to help allocate this money to appropriate projects and initiatives. These include, amongst others, the recent establishment of a New Silk Road Fund (NSRF), the establishment of the Asian Infrastructure Investment Bank (AIIB) and the government directing large sums of its foreign exchange reserves and several of its largest state-owned banks to the initiatives. If carried out at full scale, the implementation of the Belt and Road will cover a long time span of at least 30 to 40 years. The year 2049 is often referred to as a key milestone as it is the year when the 100th anniversary of the establishment of the People's Republic of China will be celebrated (PwC, 2017).

\section{Strategic Partnerships}

China has lost no time in building strategic partnerships with most of the 65 States and related regional or sub-regional organizations along the Belt and Road. The Belt and Road offers opportunities for region-wide cooperation as well as bilateral and multilateral cooperation. Following China's example, partnerships are one way of developing strength among smaller nation states.

Vietnam has already negotiated at least fourteen strategic partnership agreements. Its first agreement was with the Russian
Federation in (2001). This agreement was followed by agreements with Japan (2006), India (2007), China (2008), South Korea and Spain (2009), the United Kingdom (2010), and Germany (2011). In 2013, Vietnam negotiated an additional five strategic partnership agreements with Italy, France, Indonesia, Singapore, and Thailand, with India in (2014). In 2015, a strategic partnership was developed with the Philippines as both nations have expressed concern "over the ongoing massive land reclamation activities that pose threats to the peace and stability in the region as well as the lives of many people across the various coastal states" (Thayer, 2015). Vietnam's on-going negotiations with the Philippines represent a determined diplomatic effort to shore up Vietnam's relations with fellow members of the Association of Southeast Asian Nations (ASEAN). The Vietnam-US Bilateral Trade Agreement (BTA) took in effect in late 2001, and the US has always been the largest export market for Vietnam.

Strategic partnerships have also been initiated by Vietnam with China through China's opening of the photovoltaic industry in Vietnam (Lee, 2017). In the first quarter of 2017 Vietnamese government data shows Chinese mainland's contracted investment hit US $\$ 824$ million, representing 10.68 percent of the total foreign investment Vietnam received (Lee, 2017). The opportunity for Vietnam to create joint platforms for manufacturing and industrial capacity cooperation with China shows continued interest by the two countries in finding ways to promote Vietnam's Two Corridors and One Economic Circle plan (Xinhua, 2017). The Silk Road Fund, founded in December 2014, has supported launching of a series of key projects. As part of the effort to establish a legal framework that supports sustainable projects for the Belt and Road Initiative, the Chinese Ministry of Environmental Protection published a non-binding Guideline for Achieving Green Belt and Road on April 26, 2017.

\section{The Belt and Silk Road Disputes}

To understand better the challenges and complexities of the One Belt, One Road initiative, and the position of Vietnam as a critical player in the process, it is important to review the July 12, 2016 decision of the International Tribunal on the Law of the Sea (ITLOS). According to the analysis of leading scholars and experts, there are at least six major claimants to the resources in the South China Sea - China, the Philippines, Vietnam, Malaysia, Brunei, and Indonesia (Dutton, 2011; Bautista, 2011; Brantley, 2006; Womack, 2006; Duong 2007; Nguyen, 2001; Mito, 1998; Valencia et al., 1997; Dubner, 1995; Samuels, 1982; Chiu \& Park, 1975).

The 2016 Arbitral decision by the International Tribunal on the Law of the Sea helped to clarify the features in the South China Sea that were the subject of the dispute (ITLOS, 2016). In this landmark decision by ITLOS, the tribunal decided the following actions on the part of China were unlawful: (1) interfering with Philippine petroleum exploration; (2) attempting to regulate 
foreign fishing; (3) failing to prevent Chinese fishing; and constructing installations and artificial islands. In joining the Law of Sea Convention (ITLOS), the Philippines and China agreed to its compulsory dispute settlement process to resolve disputes. As provided in the Convention, the decision is final and legally binding on the Philippines and China, but not on the other claimants that may assert sovereignty in the South China Sea (ITLOS, 1982). The U.S. Department of State has urged all claimants to avoid provocative statements or actions and use the decision as an opportunity to resolve disputes peacefully. The U.S. expresses hope and expectation that both parties will comply with their obligations (USDOS, 2017). China has criticized the Award on several grounds including the ground that China has historic rights in the South China Sea that the Tribunal cannot terminate or ignore. Significantly, the United States is not a party to the Convention on the Law of the Sea, but the U.S. policy since 1983 has been to abide by the Convention with respect to traditional uses of the ocean, which it considers to reflect customary international law (DoS, 2017).

Shortly after the decision, The European Union issued a statement noting China's legal defeat over the South China Sea but avoided direct reference to Beijing, reflecting discord among EU governments over how strongly to respond to the court ruling (EU, 2016). While the European Union is neutral in China's dispute with its Asian neighbors in the South China Sea, Britain, France and Germany want to make clear that Beijing must uphold international law as it seeks a bigger global role (Wong and Edwards, 2016). But speaking with one European voice has become difficult as some smaller governments, including Poland, Latvia, Hungary and Greece, rely on Chinese investment and are unwilling to criticize Beijing despite its militarization of South China Sea islands. Croatia and Slovenia have their own maritime dispute and are worried about setting precedents by coming out too strongly in favor or against the court in The Hague that ruled on the South China Sea case, the Permanent Court of Arbitration. In the statement of all $28 \mathrm{EU}$ governments, the bloc acknowledged the ruling in The Hague and said it was "committed to maintaining a legal order of the seas and oceans" (EU, 2016). After three days of difficult talks in Brussels to reach a common position, similar to the U.S. position, the European Union said all sides should resolve the maritime dispute "through peaceful means, to clarify their claims and pursue them in respect and in accordance with international law" (EU, 2016).

\section{Governance of the Belt and Road Projects}

There is no structure or framework for the building of the South China Belt and Silk Road. The building of the land and sea portions of the Silk Road requires different strategies, policies, and frameworks. They also require an understanding of the various laws and regulations that require compliance depending on the location of the infrastructure.
The Belt and Road is a one of a kind project to which traditional approaches to development are difficult to apply. To succeed with the building of this project, national, regional and even transnational approaches should be considered. National laws and regulations will be applicable to projects built within a particular country, but international standards are applied to those projects that cross countries and geographic boundaries. For example, dividing-up land routes based on land ownership will be far simpler than dividing up the South China Sea where there are no existing laws governing borders and boundaries for the body of water that lies outside the international law of the sea's artificial boundaries based on nautical miles of the land portion from the sea portion.

China faces many challenges in the implementation of the Maritime Silk Road that it does not face with the land route. In developing the Silk Road, China is creating a new model of global governance that combines national, regional, and multinational elements. As described by one scholar, "[o]n the one hand, it looks like a regional economic integration mainly because of two factors. One is its geographical coverage, that is, all Asian and European States along the Silk Road and the Maritime Silk Road. The other is its fields of cooperation, that is, largely the economic field, or economic cooperation as its core. On the other hand, the Belt and Road does not look like other existing regional economic integration which has set up a uniform institutional structure, or even established a supranational structure" (Zeng, 2016).

The ability of the claimants to develop ownership without borders requires new approaches and transformative governance structures that will draw upon multiple models of integration including bilateral, multilateral, regional, transnational, partnership and shared communities of common destiny of the whole of mankind (Zeng, 2016). The Belt and Silk Road also requires a structure to manage the numerous contracts and relationships among businesses, nations, and individuals.

In the past two decades, scholars have offered up various models to resolve the Spratly Disputes including adjudication under international law, bilateral investment treaties, national legislation, and arbitration. A few of the most appealing models recommend a dispute resolution mechanism based on trust, transparency and joint development. These models include a 40 year joint development agreement modeled after the Timor Gap Treaty (Mito, 1998); sharing of resources of the South China Sea (Valencia et al., 1997); and the development of a Spratly joint management authority based on fairness and efficiency (Cui, 2003). These models all represent the importance of shared responsibility and joint authority, which could be implemented through joint development agreements, various bilateral or multilateral treaties, or through memorandums of understanding executed by each country. Commentators have referred to the Timor Gap Treaty which served to strengthen previously strained relations between Australia and Indonesia as a "triumph 
of compromise," and an "imaginative approach to breaking the deadlock in boundary negotiations" (see Mito, 1998). Another interesting analogy for the South China Sea is the Svalbard Treaty commonly known as the Spitsbergen Treaty signed in Paris 9 February 1920. The Treaty presently has 40 member nations including China and Russia. The treaty recognizes the sovereignty of Norway over the Arctic archipelago of Svalbard, at the time called Spitsbergen. The treaty regulates the demilitarization of the archipelago. The signatories were given equal rights to engage in commercial activities (mainly coal mining) on the islands. Presently, only Norway and Russia are making use of this right. This innovative approach to sovereignty has contributed to regional security by avoiding conflict and, yet creating opportunity for participation by all treaty members in the rich resources of the archipelago. There is much to be learned from this innovative solution to boundary disputes by the Southeast Asian nations. Vietnam and China could lead the way on shared resources in the South China Sea through the development of a joint venture arrangement where all claimants in the South China Sea could participate (Greiman, 2014). Project governance must be transparent, provide for accountability, and be fair in perception and practice to be sustainable. There must be an evaluative process for measuring the success and failures of the system, and there must be an ability to address the weaknesses in the system and reform the process to ensure continued viability. Evaluation of governance structures provides a space in and through which different parties-some of whom may otherwise be separated by vast power and cultural differences-can engage with one another (Adler et al., 2009).

\section{Foreign Direct Investment Strategies for Vietnam}

To open up opportunities for Vietnam on the Belt and Silk Road, the focus must continue on reducing trade barriers and creating a transparent and safe environment for investment. Vietnam has taken some important steps in developing frameworks for foreign direct investment and that process should continue to enable Vietnam to be prepared for evolving opportunities. Legal scholars have recognized that Vietnam still has serious hurdles to overcome if substantial financing from foreign direct investment is to become a reality. Further research will focus on an in-depth analysis of the areas where Vietnam must continue to place resources to shore up its institutions and its government for the vast opportunities that are presented from development of the Belt and Maritime Silk Road. A brief summary of four significant areas for reform and advancement is provided below and is the subject of future research. These areas are: (1) expansion of public private partnership legislation; (2) bilateral investment treaty development and country partnership strategies; (3) technology transfer; and (4) State Owned Enterprise (SOE) reform. The World Bank in its recent overview of Vietnam noted that while broad macroeconomic stability remains, some vulnerabilities, including fiscal imbalances and unresolved asset quality problems in the banking sector, require attention. A stronger domestic private sector can also serve as an engine for growth, as would accelerated reforms in the SOE sector (World Bank, 2017).

\subsection{Public Private Partnership Legislation}

After over two years of development and drafting, Vietnam's Decree 15 on Public Private Partnerships (PPP Decree) came into effect on 10 April 2015. In developing the PPP Decree, a number of lessons were taken from challenges faced by investors and government alike under the previous regulations. The PPP Decree aims to offer a more consistent and effective regime for all PPP projects (including BOT, BTO and BT), and provides more guidance for both State authorities and investors in order to facilitate project preparation and implementation (Boots, 2016). The PPP Decree is designed to focus on improving the transparency of the project development process in order to promote more foreign investment in infrastructure development across key sectors such as transportation, energy, environment, water supply, and waste treatment (WB, 2016). Though the PPP Decree is a good start, the development of the PPP process is still in its early stages in Vietnam. The implementation process requires support and coordination among all authorities involved in the PPP process as well a legal framework that will incorporate technical and financial requirements. The framework should enable project viability, streamline regulations to attract private participation, and improve capacity throughout the government to oversee and control the partnerships and most important to ensure accountability by all participants in the PPP process.

\subsection{Bilateral Investment Treaties and Country Partnership Strategies}

In principle, Vietnam has committed to maintain a policy of national treatment for foreign direct investment but restrictions in terms of foreign ownership vary depending on the sectors in which the foreign investor will operate. For instance, foreign investors may invest without any restriction in ownership of projects related to the production of electricity. In contrast, foreign ownership is restricted with respect to establishing telecommunications network infrastructure, which requires state participation, and investing in the oil and gas sector in Vietnam. Vietnam should reconsider its provisions in its bilateral investment treaties with key states or in other international treaties that may afford relief from such restrictions. Vietnam has signed more than 60 double tax avoidance treaties, including one with the United States, which set conditions for relief from income tax, including possible exemption from withholding tax or reduction of the withholding tax rates (Vietnam-US, 2015). These treaties must be examined to make sure all possible burdens are lifted.

In its Country Partnership Strategy, 2012-2015 Final Review Validation, the Asian Development Bank said Vietnam should stimulate technological innovation and product diversification to continue transitioning to a hub for high value-added manufacturing (Tiếng Việt, 2012). The ADB noted that the 
country should pursue innovation to improve the quality of goods for the domestic market and to try to increase the quality of Vietnamese firms participating in regional production networks. For 2017, the government has set Vietnam's GDP growth target at 6.7 percent, while growth levels for the following years are expected to reach levels of at least seven percent. For a large part, increased trade will fuel this growth. In 2016, Vietnam signed the Vietnam - EU Free Trade Agreement (EVFTA), eliminating trade tariffs by 2018, among other provisions. While the United States has recently abandoned the Transpacific Partnership (TPP) agreement, Vietnam continues to diversify its economic partners, through increased ASEAN integration, the proposed Regional Comprehensive Economic Partnership (RCEP), covering 3.4 billion people, and which may emerge as the alternative to the TPP, and the EVFTA. Expanding opportunities for developing Bilateral Treaties and partnership strategies with other countries and the private sector on the Belt and Road is essential to Vietnam's success in the region.

\subsection{Technology Transfer}

Technology transfer is another important legal aspect of Vietnam's growth on the Silk Road. Vietnam has had a difficult time attracting strategic shareholders due to specific requirements placed on these shareholders, such as the transfer of technology or expertise. Nguyễn Thị Tuệ Anh, Deputy Director of the Central Institute for Economic Management, notes that the FDI sector is not linked closely with domestic firms, which hinders technology transfer. At the same time, domestic firms have not engaged deeply with the supply chain of the FDI sector in Vietnam (Vietnam News, 2017). Other experts, say it is time Vietnam focused on attracting investment from giant corporations in the world. As the Government accelerates efforts to improve the investment climate through better technology transfer laws, Vietnam will become more attractive to foreign investors.

\subsection{Privatization Program for State Owned Enterprises}

Another major concern to attracting foreign direct investment is the status of Vietnam's State Owned Enterprises disfavored by most investors. According to the 2014 Law on Enterprises, a state-owned enterprise (SOE) is an enterprise in which the state holds 100 percent of its equity, a definition that does not follow international standards and obscures the true number of SOEs in Vietnam.

In 2015, Central Institute for Economic Management (CIEM), a government think tank, reported there were 2,000 SOEs in Vietnam where the state retained a majority interest, and 781 SOEs where the state retained 100 percent ownership. The World Bank's 2035 Report estimated over 3,000 total SOEs under majority state control, employing around 1.5 million people, and accounting for 15 percent of all enterprise employees (WB, 2016). The greatest complaint about SOEs from the investor community is that they do not operate on a level playing field with domestic companies and they continue to benefit from preferential access to resources such as land, capital, and political access.

While foreign investors are allowed to buy shares in SOEs in accordance with WTO commitments, the majority of SOEs that were privatized in 2014-2015 offered such a small percentage (often just 2-3 percent) to private investors that most SOE's failed to attract more than nominal interest from foreign investors (DoS, 2016). Additional drawbacks to foreign investment in SOEs include an overall lack of transparency, weak corporate governance, and unclear management structure (DoS, 2017). Domestic and foreign investors are permitted to buy shares through a public auction, or invest as a strategic shareholder. If Vietnam hopes to succeed in attracting and maintaining foreign investment, it must supplement its privatization initiatives with a commitment to global standards of transparency for SOEs, be based on fair access to the stock market, function independently of political intervention, and must provide relevant financial information to the investing public (Le and Hartley, 2016). Information disclosure by State Owned Enterprises (SOEs) is part of a broader agenda to promote greater public sector transparency in Vietnam. Recent studies by the World Bank and others have shown that despite progress, compliance with legal requirements for transparency remains a challenge across a wide range of public sector governance areas in Vietnam (WB, 2014).

\section{Conclusion}

Vietnam is well positioned to be a valuable player both on the Economic Belt and on the Maritime Silk Road projects. Vietnam should look to the private sector as an innovator, sponsor and strategic partner. Comparing the Silk Road to other endeavors is impossible. For the Belt and Silk Road to be successful, the current governance must be opened-up to incorporate the private sector as an important player in the development of the belt and road partnerships and multilateral and bilateral agreements. The private sector continues to express interest in participating, but without clear roadmaps, it will be far more difficult to move forward. Private sector investment requires strong legal systems and protections from expropriations and nationalization. Without the expertise, financing and innovation of the private sector a government run belt road may suffer from an overly bureaucratic approach known as governmentality. The Silk Road requires a new formula of global governance and a new model of international cooperation. If China hopes to realize its dream of a community of shared destiny, it must also be willing to open up an environment of shared resources and shared responsibility.

\section{References}

- Abe, T. \& Tomiyama, A. (2015). China, Vietnam to cooperate on new trade corridor. Asian Review, 8 April.

- Adler, D., Sage, C., \& Woolcock, M. (2009). Interim institutions and the development process: Opening spaces for 
reform in Cambodia and Indonesia. 4 Brooks World Poverty Institute. Univ. of Manchester. Crossref

- Bautista, L. B. (2011). Philippine territorial boundaries: Internal tensions, colonial baggage, ambivalent conformity. Journal of Southeast Asian Studies, 16 December, 35-53.

- Boots, S. (2017). The PPP Decree: an important re-boot for Vietnam's PPP program. The World Bank, Public Private Partnership International Resource Center (PPPIRC).

- Chiu, H., \& Park, C.H. (1975). Legal status of the Paracel and Spratly Islands. Ocean Dev. \& International Law Journal 3. Crossref

- CPC Central Committee on National Economic and Social Development Five-Year Plan (October 29, 2015) Eighteenth Communist Party of China Central Committee of the fifth plenary session.

- Cui, W. (2003). Multilateral management as a fair solution to the Spratly disputes. Vanderbilt Journal of Transnational 36 May, 799.

- Dubner, B. H. (1995). The Spratly "Rocks" dispute - A "Rockapelago" defies norms of international law. Temple International Law, Comparative Law Journal 9 Fall 291.

- Duong, W. N. (2007). Chinese law in the global context: Following the path of oil: The law of the sea or

- Realpolitik--What good does law do in the South China Sea territorial conflicts? Fordham International Law Journal 30 (4) 1098.

- Dutton, P. (2011). Three disputes and three objectives: China and the South China Sea. Naval War College Review, 64(4).

- Economist, (2015). The New Silk Road, September 12.

- Eisenman, J. \& Stewart, D. T. (2017). China's New Silk Road is Getting Muddy. Foreign Policy, 9 January.

- European Council, Council of the European Union (2016). Declaration by the High Representative on behalf of the EU on the Award rendered in the Arbitration between the Republic of the Philippines and the People's Republic of China, 15 July.

- Greiman, V. A. (2014). Model for Collaborative Development in the South China Sea. Journal of Asian Finance, Economics and Business Vol. 1 No.1: 31-40 31. Crossref

- Greiman, V. (2011). Twenty-seventh international law symposium: The public private conundrum in international investment disputes: Advancing investor community partnerships. Whittier Law Review 32, 395.

- Guggenheim, S. (2006). Crisis and contradictions: Understanding the origins of a community development project in Indonesia, in the search for empowerment: social capital as idea and practice at the World Bank. 127. Bebbington et al., eds. West Hartford, CT: Kumarian Press.

- Guggenheim, S., Wiranto, T. Prasta, Y. and Wong, S. (2004). Indonesia's Kecamatan development program: a large-scale use of community development to reduce poverty. Global Learning Process and Conference, Shanghai. Washington, DC: The International Bank for Reconstruction and Development (IBRD), The World Bank.

- Hanoitimes (2017). Vietnam treasures importance to the cooperation with AIIB. Hanoi, March 8.
- International Tribunal on the Law of the Sea, Permanent Court of Arbitration (PCA) (2016). The South China Sea Arbitration. The Republic of Philippines v. The People's Republic of China, 12 July.

- Kim, N. (2017). Loans Championed Under China's BeltRoad Project Rise 50\% in Two Years. Bloomberg, 11 May.

- Le, T.V. and Harley, K. (2016). Privatizing State-Owned Enterprises in Vietnam: Government Dilemmas Stalled growth through the failure of SOEs is a threat to political stability. The Diplomat, 26 November.

- Lee, J. (2017). Photovoltaic industry booms in Vietnam's Bac Gian, Belt and Road Portal. Hong Kong Trade Development Council.

- Liqun, J. (2016). How will the new Asian Infrastructure Investment Bank boost development? World Economic Forum, 20 January.

- Mito, L. A. (1998). The Timor Gap Treaty as a model for joint development in the Spratly Islands. American University, International Law Review, 13, 727.

- Nguyen, H. T. (2001). Regional focus \& controversy: Maritime and territorial dispute in the South China Sea: Vietnam's position on the sovereignty over the Paracels \& the Spratlys: Its maritime claims. Journal of East Asia \& International Law, 5 Spring, 165. Crossref

- (PRC). Vision and Actions on Jointly Building Silk Road Economic Belt and 21st-Century Maritime Silk Road (2015). Issued by the National Development and Reform Commission, Ministry Foreign Affairs, and Ministry of Commerce of the People's Republic of China with State Council authorization, the People's Republic of China, March 28.

- Price Waterhouse Coopers (PwC) (2017). Repaving the ancient Silk Routes, Executive Summary. PWC Growth Markets Centre, Realizing Opportunities along the Belt and Road, May.

- Renaud, F.G. and Kuenzer, C. (eds.) (2012). The Mekong Delta System: Interdisciplinary Analyses of a River Delta, Springer, New York. Crossref

- Samuels, Marwyn S. (1982). Contest for the South China Sea. London, UK: Methuen.

- Thayer, C. (2015). The Philippines and Vietnam Forge a Strategic Partnership. The Diplomat, 10 March.

- Tiếng Việt (2012). Vietnam: Country Partnership Strategy (2012-2015). The Asian Development Bank, July.

- United Nations Belt and Road Forum for International Cooperation (2017). General Assembly of the United Nations, President of the 71st Session, Beijing.

- United Nations Convention on the Law of the Sea (1982). Opened for signature 10 December 1982, 1833 UNTS 3 (entered into force 16 November 1994).

- UNCTAD. (2014). Investment guide to the silk road, Geneva: United Nations Conference on Trade and Development.

- U.S. Department of State (DoS) (2016). Press Statement John Kirby Assistant Secretary and Department Spokesperson, Bureau of Public Affairs, Washington, DC: U.S. Department of State, 12 July. 
- U. S. Department of State (DoS) (2017). Vietnam Competition from State-Owned Enterprises. U.S. Department of State, Office of Investment Affairs Investment Climate Statement, January 24.

- Valencia, M. J., VanDyke, J. M., \& Ludwig, N. A. (1997). Sharing the resources of the South China Sea. University of Hawaii Press.

- Vietnam's Five-Year Economic Plan ((2016). Officially approved at the VIIIth National Assembly's Inaugural Session, 20-23 April 2016, Vientiane, Ministry of Planning and Investment, June 2016.

- VietnamNet (2017). Low FDI in Mekong Delta attributed to poor infrastructure, 6 April. http://english.Vietnamnet.vn/fms/business/176046/low-fdiin-mekong-delta-attributed-to-poor-infrastructure.html.

- Vietnam News (2017). Foreign investment key to Vietnamese growth: experts. Hanoi: Vietnam News., April 5.

- Vietnam-U.S. Agreement (2015). Agreement between the Government of the United States of America and the Government of the Socialist Republic of Viet Nam for avoidance of double taxation and the prevention of fiscal evasion with respect to taxes on income, July

- Weiss, MA. (2017). Asian Infrastructure Investment Bank (AIIB). Washington, DC: Congressional Research Service, February 3.

- Womack, B. (2006). China and Vietnam, Cambridge, England: Cambridge University Press.

- Wong, S-L \& Edwards, T. (2016). Discord over the South China Sea clouds Asia-Europe Summit. Reuters, July 16.

- World Bank. (2014). Transparency of State Owned Enterprises in Vietnam: Status and Ideas for Reform. Washington, DC: The World Bank.

- World Bank Country Overview, Vietnam (2017). Washington, DC: The World Bank, April 13. http://www.worldbank.org/en/country/Vietnam/overview.

- World Bank Overview (2016). Vietnam 2035: Toward Prosperity, Creativity, Equity, and Democracy, The World Bank Minister of Planning and Investment of Vietnam, Washington, DC: The World Bank Group.

- Xinhua/Ju Peng (2017). Chinese, Vietnamese presidents hold talks on ties. Xinhuanet, Xinhua News Agency, 11 May.

- Xinhua. (2017). China, Vietnam agree on closer cooperation. China Insight, Xinhua News Agency, 12 January.

- Zeng, L. (2016). Conceptual Analysis of China's Belt and Road Initiative: A Road towards a Regional Community of Common Destiny, Chinese Journal of International Law 15(3): 517-541, September. 